\title{
Free Education For The Girl Child In Public Secondary Schools In Nigeria: It's Impact On Enrolment
}

\author{
Anna Preye Brambaifa, (PhD) \\ Department Of Curriculum Studies And Educational Technology \\ Faculty Of Eduation \\ University Of Port Harcourt, Rivers State, Nigeria
}

\begin{abstract}
All over the world, education has been recognized as an effective tool for societal development. Educating the girl-child has however faced impediments as a result of societal prejudice which has immensely affected the enrollment of girls in secondary schools. In recognition of this impediment, numerous governments have put in place measures such as "free education for all" to encourage gender balance in the educational system. This study is therefore informed by the need to analyse the impact of free education for the girl child and its impact on enrolment in secondary schools. The research established that free education for all in the long term favors the male child because of socio-economic and religious impediments affecting the girl. The sustainability of these measures has over the years being affected by poor implementation, financing and accountability. Thus, employing a stratified ransom random sampling technique and structuring a 4 pointer likert scale questionnaire titled "Free Education and Enrolment for the Girl-Child in Public Secondary School Questionnaire" (FEEGPQ) which used to obtain responses from the participants. A correlation coefficient of 0.89 was obtained using the split-half reliability method. The data was analyzed using the (statistical package for social science) SPSS version 22 and the results indicated that free education targeted at girls will greatly impact the enrolment of girls while identifying that location plays no role in how free education is perceived by the public.
\end{abstract}

Keywords: Education, Girl-child, Free education,

\section{INTRODUCTION}

Education they say is the key to unlocking the potentials of any society. As such, no society can experience economic, political, technological and societal development without a comprehensive educational scheme in place. This is evident in the level of development presently seen in countries such as Germany, United Kingdom and China who have put in place efficient and effective educational schemes.

The internet, battery powered cars, robots, mobile phones are testament to the technological advancements of these countries. As such, if developing countries are to make progress in their economical, societal and technological development, there is need therefore for effective and efficient educational policies to be implemented.

One of the key areas in the educational policies that have seen countries such as China, United States and Switzerland develop is equal participation in education. These policies ensure that the enrolment rate in these countries remain high while giving no room for gender discrimination in their educational system.

In the Nigerian context however, the gender equity in school enrolment still remains a challenge and this consequential effects on national development. 
Researchers highlight that male enrolment in school is higher than the female in primary, secondary and tertiary stages with primary schools having $56 \%$ of males when compared to $44 \%$ whereas the secondary enrolment levels was recorded as $53 \%$ of males and $47 \%$ for females but the highest was recorded in that of the university level which recorded $73 \%$ for males and $27 \%$ for females (Amuda et al., 2016).

This is rather worrisome, because the population of women in the country estimated to be $49 \%$ of the population in the country should not be overlooked and also the endorsement of equal right to education regardless of gender, ethnicity and religious belief by the United Nations in the Universal Declaration of Human Rights (Afu et al., 2017).

Hence, the situation where there is gender imbalance in the school enrolment particularly the girl-child should not be in practice (Abiagwu \& Unachukwu, 2008). Scholars have opined that this imbalance has been encouraged by poverty, ignorance, traditional and religious impediments to mention but a few (Onyido \& Brambaifa, 2011). These have serious implication for the society at large.

Over the years numerous policies have been introduced to improve the standard and delivery of education in Nigeria. These policies though impressive have still failed to meet their objectives this can be partly attributed to corruption, policy continuation, funding and gender inequality. Gender inequality is the participation in every phase of the educational process in Nigeria particularly with regard to enrolment in the secondary school education has immensely impacted the development of the educational process in Nigeria. One of such policies adopted by the Nigerian government is the free education policy that seeks to encourage the enrolment of the girl-child as one of the Sustainable Development goals that is to be attained by every nation by 2030 is to ensure that "all boys and girls complete free, equitable and quality primary and secondary education leading to relevant and effective learning outcomes"..

\section{Free Education}

The term free education is a combination of two words "free" and "education". It simply refers to the provision of education by an individual or corporate body without cost or payment (Ige, 2015). Countries such as USA, Canada, Australia, Uganda are currently offering free secondary education.

Prior to the restructuring of Nigeria in 1951 into West, East and North regions, education was placed on a parallel legislative list between the federal and regional government. The implication of this afforded both level of governments the right to build, fund and manage their educational institutions (Ige, 2015; Evans-Obinna \& Ndieze, 2017).

The universal primary education (UPE) programme was introduced in 1955 by the government of the western region in a bid to stimulate the enrolment of citizens in school (Ajayi, 2008). The idea was to place emphases on providing free education to primary school aged children. This policy by the government of the western region saw an increase in the access of the facilities of primary schools from 566,766 to 802,534 citizens from 1955 to 1970. A consequence of this commendable policy by the government of the western region, was the adoption of a similar policy by the government of the eastern region in 1957 and Lagos, the federal capital as at that period. Unfortunately the programme was abandoned in the east as a result inefficient planning, implementation and financial bankruptcy bringing an end to the free education policy (Ajayi, 2008; Ige, 2015). 
The constitutional change in governance in 1979 brought about the change of regulations from military decree system to constitutional legislations that also allowed the establishment of parallel educational facilities in the federal, state and local governments. This saw the United Party of Nigeria offer free education from primary to secondary level in Ogun, Oyo, Bendel and Lagos states where it controlled (Lawal, 2012; Ige, 2015). As a result of this development, these states experienced increased educational development when compared with other states. This was however, suspended by the military government in 1983 on the basis that it was expensive, cosmetic and it was depriving the provision of quality education because of heavy financial requirements. Free education however, reared its head again after the inauguration of another civilian government in 1999; this time around it was based more in areas such as provision of facilities for schools, payment of SSCE and JSCE fees for eligible students and scholarship schemes/awards to students (Ige, 2015).

The UBE programme introduced by former president Obasanjo also sort to provide partial form of free basic education for children, unfortunately this was not adopted by many states in the country (Unit, 2009). During the tenure of presidents Yaradua and Jonathan more efforts were made to offer a certain version of free education while the current administration of Buhari continues to offer free education through approaches such as scholarships.

Free education in Nigeria continues to stir debates between scholars. Those in support of its introduction highlight that a significant number of Nigerians are presently living in poverty and cannot meet the requirements to attain education. Furthermore, limited access to education, cultural and religious beliefs continues to inhibit the education of the Nigerian populace (Onwuameze, 2013) This challenges have influenced the reason behind poverty alleviation policies such as National Economic Empowerment and Development strategies, national poverty eradication programme and structural adjustment programs to mention but a few. Another school of thought however argues against the introduction of free education. According to them the cost of running such venture will be too demanding on Nigeria's ailing oil revenue dependent economy (Adeyemi, 2011). According to Dabaleen et al (2000) the standard of education in Nigeria is on a free fall and introducing free education encourages the mass promotion of students from one to another regardless of how they have performed in a bid to save cost which will ultimately weaken the standard of education in the country. However, if any country is to experience development in all sectors, its educational sector must be thriving, there is justification for education funds derived from taxes be spent on the education of the populace particularly the girl child whose importance to national growth is key.

\section{Statement of the problem}

Despite the obvious benefits of education, the education of the girl-child continues to stir up debates among scholars. Mainly as a result of the disparity observed in girl-child enrolment in schools particularly in secondary school education which has been attributed to poverty, cultural and religious conflicts. According to Udeozor (2003) the woman is seen as a child bearer, kitchen expert, house keeper with low intellect. This view has encouraged the low turn of the girl-child in school across the ground and has serious developmental implications for the Nigerian state

Although over the years the Nigerian government has introduced policies like free education to tackle the gender gap in the enrolment in secondary schools, challenges have continued to impact the effectiveness of such policies such as in adequate funding, poor implementation and poor accountability. Most free education strategies employed by the Nigerian government aim to offer equal opportunities for both the male and female child and this in the long run, 
encourage the enrolment of more male students as a result of the patriarchal belief that continues to exist in the Nigerian society. As such, placing a level playing ground for both genders in the Nigerian context favours the male-child.

\section{Objectives of the Study}

For the purpose of this study, the following objectives were addressed:

1. To investigate if free education for the girl-child will increase school enrollment in public secondary schools.

2. To establish if socio-economic and religious challenges impact the enrolment of the girlchild in public secondary schools.

3. To compare the perception of respondents from urban locations and rural location of the study area on free education.

\section{Hypotheses}

The hypotheses which guided the study was tested at 0.05 level of significance and are as follows:

1. Free education will not increase school enrollment of the girl-child in public secondary schools significantly.

2. Socio-economic and religious challenges do not significant impact the enrolment of the girl child in public secondary schools.

3. There is no significant difference between the perception of respondents on free education and girl-child enrolment from the urban and rural locations of the study area.

\section{METHODOLOGY}

For the purpose of this study, the ex-post factor research design was adopted.

\section{Scope of the study}

The study was conducted in the Niger Delta region. Rivers state is selected purposely for this study because of its economic and strategic position it occupies in this region. Rivers state is made up of 23 local government areas. The study focused on three local government areas namely Omuma, Ogba and Etche local government.

\section{Population for the study}

The population of the research comprises of young girls, teachers and parents. The population size was not determined, hence the convenience sampling technique was introduced.

\section{Sample of the study}

Stratified random sampling technique was adopted to select 170 participants for the study.

\section{Instrumentation}

The primary instrument for the research is fashioned along the 4 point rating scale that sort the elicit response from the structured survey questionnaire tagged "Free Education and Enrolment for the Girl-Child in Public Secondary School Questionnaire" (FEEGPQ). The instrument was divided into two sections. Part 1 addressed the bio data of the respondents while part 2 generated data on the impact of free education of the girl child on enrolment. The value of 2.5 was employed to interpret the mean value indices of the variables of the research. A mean score of 2.5 was employed as moderate index while indicating the minimum acceptance level. 


\section{Validation}

The instrument was content validated and the split-half reliability method was employed to determine the reliability coefficient of the internal consistency and stability of the instrument.

\section{Data Analysis}

The data recorded for the research was analysed employing IBM SPSS version 22 and consisted of descriptive analysis and $t$ statistics.

\section{RESULTS}

Hypotheses One: "Free education will not increase school enrollment of the girl-child in public secondary schools significantly".

Table 1: One-sample test-Free Education for Girl-Child

\begin{tabular}{ccccccc}
\hline & $T$ & Df & Sig (2-tailed) & $\begin{array}{c}\text { Mean } \\
\text { Difference }\end{array}$ & \multicolumn{2}{c}{$\begin{array}{c}\text { 95\% Confidence Interval } \\
\text { of the difference }\end{array}$} \\
\cline { 5 - 6 } & & & & & Lower & Upper \\
Qp1 & 50.632 & 169 & .000 & 3.213 & 3.09 & 3.34 \\
Qp2 & 62.454 & 169 & .000 & 3.365 & 3.26 & 3.47 \\
Qp3 & 56.606 & 169 & .000 & 3.294 & 3.18 & 3.41 \\
Qp4 & 56.567 & 169 & .000 & 3.312 & 3.20 & 3.43 \\
Qp5 & 61.513 & 169 & .000 & 3.441 & 3.33 & 3.55 \\
$\mathrm{t}_{\text {cal }}$ & $\mathbf{5 7 . 5 5 4}$ & & & & & \\
\hline
\end{tabular}

From the analyses, the result obtained above is statistically significant as the test statistic $t$ is equal to 57.554 at 0.05 level of significance with 169 degrees of freedom. It can be observed from the result that $t_{\text {cal }}$ is greater than $t_{\text {tab }}$ in essence 57.55> 2.060. Hence, the $H_{0}$ that free education will not increase school enrollment in public secondary schools significantly is rejected. The alternate hypothesis was strengthened by above the threshold figure of 2.5 for the mean difference which was presented as (Qp1-3.21, Qp2 - 3.37, Qp3 - 3.29, Qp4 - 3.31 and Qp5 - 3.44) in table 1 above.

Hypotheses Two: Socio-economic and religious challenges do not significantly impact the enrolment of the girl child in public secondary schools.

Table 2: One-Sample Test- Socio-economic, religious challenges and enrolment

\begin{tabular}{|c|c|c|c|c|c|c|}
\hline & \multirow[t]{2}{*}{$\mathrm{T}$} & \multirow[t]{2}{*}{ Df } & \multirow[t]{2}{*}{ Sig (2-tailed) } & \multirow[t]{2}{*}{$\begin{array}{c}\text { Mean } \\
\text { Difference }\end{array}$} & \multicolumn{2}{|c|}{$\begin{array}{c}95 \% \text { Confidence Interval } \\
\text { of the difference }\end{array}$} \\
\hline & & & & & Lower & Upper \\
\hline Qp6 & 56.007 & 169 & .000 & 3.335 & 3.22 & 3.45 \\
\hline Qp7 & 34.315 & 169 & .000 & 2.747 & 2.59 & 2.91 \\
\hline Qp8 & 42.059 & 169 & .000 & 2.953 & 2.81 & 3.09 \\
\hline Qp9 & 62.619 & 169 & .000 & 3.406 & 3.30 & 3.51 \\
\hline Qp10 & 30.603 & 169 & .000 & 2.518 & 2.36 & 2.68 \\
\hline Qp11 & 60.443 & 169 & .000 & 3.394 & 3.28 & 3.50 \\
\hline $\mathrm{t}_{\mathrm{cal}}$ & 47.674 & & & & & \\
\hline
\end{tabular}

From table 2 above it can be deduced that that from the statistically significant result which establishes that test statistic $t$ is equal to 47.674 at 0.05 level of significance with 169 degrees of freedom. It can further be deduced from the result that $t_{\text {cal }}$ is greater than $t_{\text {tab }}(47.67>2.060)$ hence the hypotheses that Socio-economic and religious challenges do not significant impact the enrolment of the girl child in public secondary schools is rejected. It can be observed that 
item 9 of the instrument represented by Qs9 has the highest magnitude of mean difference (3.40) then Qs11 (3.39), Qs6 (3.33), Qs8 (2.95), Qs7 (2.74).

Hypotheses Three: There is no significant difference between the perception of respondents on free education and girl-child enrolment from the urban and rural locations of the study area.

Table 3: One-way Analysis of Variance (ANOVA) for difference in the perception of participant at Urban and Rural location.

\begin{tabular}{|c|c|c|c|c|c|c|}
\hline & & $\begin{array}{c}\text { Sum of } \\
\text { Squares }\end{array}$ & Df & $\begin{array}{c}\text { Mean } \\
\text { Square }\end{array}$ & $\mathrm{F}$ & Sig. \\
\hline \multirow[t]{3}{*}{ Qp1 } & Between Groups & .597 & 1 & .597 & 1.123 & $.291^{*}$ \\
\hline & Within Groups & 89.315 & 168 & .532 & & \\
\hline & Total & 89.912 & 169 & & & \\
\hline \multirow[t]{3}{*}{ Qp2 } & Between Groups & 1.121 & 1 & 1.121 & 2.290 & $.132^{*}$ \\
\hline & Within Groups & 82.267 & 168 & .490 & & \\
\hline & Total & 83.388 & 169 & & & \\
\hline \multirow[t]{3}{*}{ Qp3 } & Between Groups & 1.384 & 1 & 1.384 & 2.394 & $.124^{*}$ \\
\hline & Within Groups & 97.093 & 168 & .578 & & \\
\hline & Total & 98.476 & 169 & & & \\
\hline \multirow[t]{3}{*}{ Qp4 } & Between Groups & 2.077 & 1 & 2.077 & 3.090 & $.081^{*}$ \\
\hline & Within Groups & 112.255 & 168 & .672 & & \\
\hline & Total & 114.331 & 169 & & & \\
\hline \multirow[t]{3}{*}{ Qp5 } & Between Groups & 2.451 & 1 & 2.451 & 4.342 & 039* \\
\hline & Within Groups & 94.843 & 168 & .565 & & \\
\hline & Total & 97.294 & 169 & & & \\
\hline \multirow[t]{3}{*}{ Qp6 } & Between Groups & 0.251 & 1 & .251 & .497 & $.482^{*}$ \\
\hline & Within Groups & 84.744 & 168 & .504 & & \\
\hline & Total & 84.994 & 169 & & & \\
\hline \multirow[t]{3}{*}{ Qp7 } & Between Groups & .578 & 1 & .578 & 1.079 & $.301^{*}$ \\
\hline & Within Groups & 90.016 & 168 & .536 & & \\
\hline & Total & 90.594 & 169 & & & \\
\hline \multirow[t]{3}{*}{ Qp8 } & Between Groups & 1.152 & 1 & 1.152 & 1.058 & $.305^{*}$ \\
\hline & Within Groups & 182.972 & 168 & 1.089 & & \\
\hline & Total & 184.124 & 169 & & & \\
\hline \multirow[t]{3}{*}{ Qp9 } & Between Groups & .547 & 1 & .547 & .474 & $.492^{*}$ \\
\hline & Within Groups & 193.900 & 168 & 1.154 & & \\
\hline & Total & 194.447 & 169 & & & \\
\hline \multirow[t]{3}{*}{ Qp10 } & Between Groups & 1.843 & 1 & & & \\
\hline & Within Groups & 100.045 & 168 & 1.843 & 3.095 & $.080^{*}$ \\
\hline & Total & 101.888 & 169 & .596 & & \\
\hline \multirow[t]{3}{*}{ Qp11 } & Between Groups & .035 & 1 & .035 & .042 & $.838^{*}$ \\
\hline & Within Groups & 141.588 & 168 & .843 & & \\
\hline & Total & 141.624 & 169 & & & \\
\hline
\end{tabular}

Not Significant; $p^{*}>.05$

The result obtained on table 3 above indicates that the differences in the mean scores observed at various levels of the questionnaire items on the comparison of the perception of participants on free education and girl-child enrolment from the urban and rural locations of the study area does not show any statistical significant difference. 


\section{DISCUSSION}

From the results obtained it can be deduced that free education can significantly impact on gender enrollment in senior secondary schools. According to Abbagana (2013) the cost of educating in Nigeria has immensely impacted the education of the girl-child. Therefore a situation where free education is introduced for the girl child will experience accelerated enrolment for the girl-child in secondary schools. According to Saleh \& Kwache (2012) where free education is introduced, parents and guardians would avail their daughters the opportunity to attend if they have nothing to lose.

The results of data for hypothesis two which were analyzed establish that socio-economic and religious challenges significantly affect the enrolment of the girl-child in public secondary schools. The results on Qs9, Qs11, Qs6, Qs8, Qs7 reveal a lot. The cost of educating the girl for low income earning parents, the girl is believed to be in charge of the kitchen and her siblings, they are required to help in meeting the financial obligations of their parents, the rejection of western education by the Muslim, economic benefits derived by parents for child marriage are the most significant challenges to the enrolment of the girl child in secondary education. This finding is in agreement with the opinion of Onyido \& Brambaifa (2019) who highlight that poverty, cultural and religious impediments affect the enrolment of the girl child. The findings from the third hypothesis establish that the perception of participants of the survey at both urban and rural locations of the study area on free education of the girl child and enrolment is not significantly different,

The ANOVA test ran on hypothesis three showed no statistically significant difference at 169 degrees of freedom and .05 level of significance. Furthermore, it further revealed that the differences in mean scores shown at various levels of the questionnaire items on the comparison of the perception of participant at rural and urban location of the study are on free education and enrolment does not show any statistical difference. It such it can be concluded that the responses obtained from the participant at both rural and urban locations in Delta state were common.

\section{CONCLUSION}

It has been established by this research which sort to investigate free education for the girl child and its impact on enrolment in public secondary schools that the girl-child endures disturbing levels of discrimination with respect to education which is a violation of her human right. It has also highlighted that the implementation of free education in Nigeria has faced challenges as a result of inadequate financing, poor accountability and implementation. While establishing from its research in urban and rural locations that free education for the girl-child will significantly impact the enrolment of the girl-child in public secondary schools, socioeconomic and religious impediment impact the enrolment of the girl child in public secondary schools while showing that the location plays no role in how free education is perceived by the public.

\section{References}

Abiagwu, C. O., \& Unachukwu, G. O. (2008). Gender Equity Employment in Polytechnics in South East Zone Of Nigeria: Implication for Affirmative Action. African Research Review, 2(1), 48-63.

Abbagana, K. K. (2013). Female-child education: a critical issue for national development in Nigeria. Journal of Education and Leadership Development, 5(2), 1-8.

Adeyemi, T. 0. (2011). Financing of education in Nigeria: An analytical review. American Journal of social and management sciences, 2(3), 295-303.

Afu, M.,Gbobo, V., Ukofiai, I. \& Suleiman., Z. (2017) Effect of Gender Imbalance in The Enrolment of Students in Public Secondary Schools in Gwagwalada Area Council, Federal Capital Territory, Nigeria International Journal of Scientific Research in Education, Vol. 10(2), 201-211. 
Ahmed, S. (2015). Public and private higher education financing in Nigeria. European Scientific Journal, ESJ, 11(7).

Ajayi, S. A. (2008). The development of free primary education scheme in Western Nigeria, 1952-1966: An analysis. OGIRISI: a New Journal of African Studies, 5(1), 1-12.

Amuda, B, G., Durkwa, H \& Bulus, A. (2016) Gender difference in enrolment in senior school certificate examination economics among secondary school students in Maiduguri Metropolis. Merit Research Journal of Education and Review, Vol. 4(7) pp. 096-100. Retrieved online from [https://www.meritresearchjournals.org/er/content/2016/July/Amuda\%20et\%20al.pdf]

Dabaleen, A., Oni, B. \& Adekola, A.O. (2000). Labour market prospects for university.

Evans-Obinna., R. \& Ndieze., R. (2017) Aceesing free education of public secondary school ro sustainable national development in Nigeria

Fabunmi, M. (2005). Historical analysis of educational policy formulation in Nigeria: Implications for educational planning and policy. International Journal of African \& African-American Studies, 4(2).

Ige, M., A (2015) Making Education Free for All Citizens: Justifiable or Not in Nigeria's Case? Journal of Poverty, Investment and Development. Retrieved online from [https://www.iiste.org/Journals/index.php/JPID/article/viewFile/17732/18116]

Lawal, B. O. (2012) the Immediate and Long Term Effects of the UPN Free Secondary Education Policy in Oyo State, Nigeria. International Review of Social Sciences and Humanities Vol. 3, No. 1 (2012), pp. 182-187. Retrieved [online] on the $13^{\text {th }}$ of February [http://irssh.com/yahoo_site_admin/assets/docs/18_IRSSH-259V3N1.131231342.pdf]

Onwuameze, N. C. (2013). Educational opportunity and inequality in Nigeria: assessing social background, gender and regional effects.

Onyido, J. A., \& Brambaifa, A. P. (2011). The Educated Women in Nigeria: An Evaluation. The Nigerian Journal of Research and Production Volume, 18(1).

Saleh, M. J., \& Kwache, P. Z. (2012). An investigation into the girl-child enrolment and completion in senior secondary school in Bauchi state Nigeria. International Research Journal of Library Information and Archival Studies, 2(2), 32-37.

Unit, G. S. (2009). Universal basic education in Nigeria: Challenges and way forward. Pakistan Journal of Social Sciences, 6(5), 252-259. 